\title{
Efektivitas Gracilaria gigas sebagai Biofilter Logam Berat Tembaga (Cu) pada Media dengan Salinitas yang Berbeda
}

\author{
Yovita Noor Hidayah, Endang Supriyantini*, Suryono \\ Departemen Ilmu Kelautan, Fakultas Perikanan dan Ilmu Kelautan, Universitas Diponegoro \\ Jl. Prof. Soedarto, SH Tembalang, Semarang, 50275 \\ Email: supri_yantini@yahoo.com
}

\begin{abstract}
Abstrak
Limbah hasil kegiatan industri dan pertanian memberikan efek negatif pada ekosistem perairan laut, seperti logam berat. Tembaga $(\mathrm{Cu})$ mempunyai potensi toksisitas yang tinggi terhadap lingkungan perairan. Dinding sel Gracilaria gigas memiliki polisakarida yang mampu menyerap logam $\mathrm{Cu}$. Tujuan penelitian ini untuk mengetahui kemampuan daya absorpsi G. gigas terhadap logam $\mathrm{Cu}$ dalam media pemeliharaan dengan salinitas berbeda. Metode yang digunakan adalah eksperimental laboratoris, menggunakan rancangan acak lengkap (RAL) dan 3 pengulangan setiap perlakuan. Perlakuan menggunakan 5 tingkat salinitas yaitu 10, 20, 25, 30, dan $40 \%$ dengan pemeliharaan selama 28 hari. Hasil penelitian menunjukkan bahwa perlakuan salinitas yang berbeda tidak berpengaruh terhadap penyerapan logam berat $\mathrm{Cu}$ oleh Gracilaria gigas $(\mathrm{p}>0,05)$. Konsentrasi logam berat $\mathrm{Cu}$ dalam media pemeliharaan tertinggi pada perlakuan $\mathrm{E}$ (40 \%o) dengan rerata nilai 0,$11 ; 0,10 ; 0,13$; dan $0,17 \mathrm{ppm}$. Kapasitas penyerapan logam $\mathrm{Cu}$ oleh Gracilaria gigas tertinggi terdapat pada hari ke 7 perlakuan A $(25 \%)$ dengan nilai rerata $0,007 \mathrm{mg} / \mathrm{g}$ dan efektivitaspenyerapan sebesar 82,77\%. Berat basah G. gigas tertinggi terjadi pada hari ke-7 dengan rerata nilai A (25\%o) 227,11 g; B (10 \%) 240,55 g; C (20 \%o) 236,44 g; D (30 \%) 221,44 g; dan E (40\%) 203,77 g. Berat mutlak dan laju pertumbuhan spesifik (SGR) tertinggi terdapat pada perlakuan E (40\%), yaitu $-34,22 \mathrm{~g}$ dan $-0,70 \%$ per hari. Semakin tinggi salinitas, maka pertumbuhan $G$. gigas akan semakin rendah sehingga akan mempengaruhi daya absorpsi logam $\mathrm{Cu}$.
\end{abstract}

Kata kunci : Gracilaria gigas., Tembaga (Cu), Absorpsi, Salinitas

\section{Abstract}

\section{Effectiveness of Gracilaria gigas as Copper (Cu) Heavy Metal Biofilter in Media with Different Salinity}

Waste from industrial and agricultural activities has a negative effect on marine aquatic ecosystems, such as heavy metals $\mathrm{Cu}$ has a high potential for toxicity to the aquatic environment. The cell wall of G. gigas has polysaccharides which can absorb the Cu metal. The purpose of this study was to determine the ability of G. gigas absorption to $\mathrm{Cu}$ metal in maintenance media with different salinity. The method used is an experimental laboratory, using a completely randomized design (CRD) and 3 repetitions of each treatment. The treatment uses 5 levels of salinity namely 10,20, 25, 30, and $40 \%$ with maintenance for 28 days. The results showed that different salinity treatments did not affect the absorption of heavy metal Cu by G.gigas ( $p>0.05)$. The highest concentration of heavy metal $\mathrm{Cu}$ in the maintenance media at treatment $E$ (40\%o) with a mean value of $0.11 ; 0.10 ; 0.13$; and $0.17 \mathrm{ppm}$. The highest absorption capacity of $C u$ by $\mathrm{G}$. gigas was on the 7th day of treatment $A(25 \%$ ) with an average value of $0.007 \mathrm{mg} / \mathrm{g}$ and the effectiveness of absorption of $82.77 \%$. The highest wet weight of G. gigas occurred on the 7th day with an average value of A (25 227) $227.11 \mathrm{~g}$; B (10\%) $240.55 \mathrm{~g}$; C (20\%) $236.44 \mathrm{~g}$; D (30\%o) $221.44 \mathrm{~g}$; and E (40 203) $203.77 \mathrm{~g}$. The highest absolute weight and specific growth rate (SGR) was found in treatment $E$ (40\%), which was $34.22 \mathrm{~g}$ and $-0.70 \%$ per day. The higher the salinity, the growth of G. gigas will be lower so that it will affect the absorption of $\mathrm{Cu}$ metal.

Keywords : Gracilaria gigas., Copper (Cu), Absorption, Salinity

\section{PENDAHULUAN}

Sumber pencemar logam berat di laut berasal dari limbah industri, domestik, pertambangan, dan pertanian. Masuknya limbah industri ke dalam perairan tanpa melalui proses pengolahan limbah yang sesuai mengakibatkan terjadinya pening-katan konsentrasi logam berat dalam air.Salah satu logam berat yang termasuk 
bahan beracun dan berbahaya adalah tembaga $(\mathrm{Cu})$. Logam berat tembaga $(\mathrm{Cu})$ memiliki berbagai manfaat seperti dalam bidang industri, yaitu elektroplating, pewarna tekstil, pengawet kayu, penyepu-han, dan lain sebagainya dimana limbah tersebut jika masuk ke dalam perairan akan menyebabkan pencemaran logam berat tembaga $(\mathrm{Cu})$. Logam berat tembaga $(\mathrm{Cu})$ adalah salah satu logam berat esensial yang masih dibutuhkan dalam tubuh organisme hidup tetapi akan bersifat toksik dalam jumlah yang banyak. Logam ini berbahaya karena cenderung terakumulasi dalam jaringan tubuh manusia dan menimbulkan keracunan (Bath et al., 2012).

Semakin meningkatnya limbah logam berat $\mathrm{Cu}$ yang masuk ke perairan dapat diatasi dengan fitoremediasi menggunakan rumput laut Gracilaria gigas. Menurut Juhaeti et al. (2005), fitoremediasi merupakan penggunaan tumbuhan untuk menghilang-kan polutan dari perairan yang terkontami-nasi.Menurut Ma'ruf et al. (2013), Gracilaria gigas merupakan rumput laut merah atau Rhodophyta yang banyak tersebar merata di perairan Indonesia dan dibudidayakan. Gracilaria gigas tumbuh di perairan dangkal dengan intensitas cahaya tinggi yang memiliki thallus berbentuk silindris atau gepeng dengan percabangan. Di atas percabangan, bentuk thallus agak mengecil dengan warna yang beragam mulai dari warna hijau-coklat, merah, pirang, dan merah coklat.Gracilaria gigas memiliki efektivitas yang relatif tinggi dalam menyerap logam toksik dalam suatu perairan. Mekanisme masuknya logam berat ke dalam thallus adalah melalui dinding sel. Pada dinding sel ini logam berat diikat oleh protein dan polisakarida sehingga logam berat menjadi senyawa yang non toksik. Gracilaria gigas mempu-nyai kandungan polisakarida dalam dinding sel yang mampu menyerap logam berat dalam bentuk ion logam berat dan senya-wa kompleks dengan zat-zat organik yang terdapat di dalam thallus (Qumain et al., 2015). Polisakarida yang terkandung dalam G. gigas adalah agar. Agar terbentuk dari campuran dua polisakarida, yaitu agarosa dan agaropektin (Phillips dan Peter, 2000).

Parameter kualitas air terutama salinitas merupakan salah satu faktor paling penting dalam penyebaran dan pertumbuhan Gracilaria gigas. Salinitas dilaut yang berubah-ubah dapat mempengaruhi pertumbuhan dan perkembangan Gracilaria gigas. Hal tersebut dikarenakan salinitas berperan dalam proses masuknya persediaan unsur-unsur yang diperlukan Gracilaria gigas sehingga secara tidak langsung mempengaruhi pertumbuhannya dan juga konsentrasi ion serta tekanan osmotik.

Berdasarkan uraian tersebut maka tujuan dari penelitian ini adalah untuk mengetahui kemampuan absorpsi Gracilaria gigas terhadap logam $\mathrm{Cu}$ pada kondisi salinitas yang berbeda.

\section{MATERI DAN METODE}

Gracilaria gigas yang berasal dari Balai Besar Pengem-bangan Budidaya Air Payau (BBPBAP), Jepara. Gracilaria gigas yang digunakan, yaitu dalam kondisi sehat, tidak cacat, masih muda, berumur kira-kira 25-35 hari, dan dipilih thallusnya yang kuat yaitu dengan melakukan pengukuran panjang maupun diameter thallus dengan menggunakan kaliper digital mulai dari bagian batang utama thallus bagian percabangan thallus pertama, kedua, dan ketiga, sedangkan pengukuran bobot massa menggunakan timbangan digital. Wadah uji yang digunakan dalam penelitian ini adalah akuarium berukuran $50 \times 30 \times 35 \mathrm{~cm}$ sebanyak 15 buah yang berisikan air laut sebanyak $30 \mathrm{~L}$ dengan aerasi. Media uji yang digunakan adalah air laut dengan salinitas yang berbeda, yaitu kontrol $25 \%$ dengan perlakuan 10, 20 30, dan $40 \%$. Penelitian ini juga menggunakan lampu TL 40 watt sebagai sumber cahaya untuk fotosintesis dan kehidupan Gracilaria gigas.

Metode penelitian yang digunakan adalah metode eksperimental laboratoris dengan rancangan percobaan acak lengkap (RAL).Perlakuan yang digunakan yaitu tingkat salinitas yang berbeda, yaitu 25 (kontrol), 10, 20, 30, dan 40 \%. Menurut Sjafrie (1990), Gracilaria gigas mampu beradaptasi pada salinitas yang sangat tinggi dengan kisaran salinitas 18-32 \%o dan salinitas yang optimal untuk pertumbuhan Gracilaria gigas adalah $25 \%$. Berdasarkan pertimbangan tersebut maka diambil kisaran minimal dan maksimal, yaitu antara 10 sampai 40 $\%$ dengan salinitas kontrol $25 \%$. Aklimatisasi Gracilaria gigas dilakukan selama 3 hari kemudian dilakukan pembuatan larutan pencemar dan salinitas yang berbeda sambil diaerasi agar homogen.

Larutan pencemar media pemeliharaan yang digunakan adalah logam berat tembaga $(\mathrm{Cu})$ berkonsentrasi $1 \mathrm{ppm}$. Hal tersebut dikarenakan menurut Yulianto (2006), rumput laut Gracilaria gigas mampu mengabsorpsi $\mathrm{Cu}$ dengan baik pada konsentrasi $1 \mathrm{ppm}$. Larutan pencemar tersebut dibuat menjadi larutan stok (stock solution) dengan konsentrasi $1000 \mathrm{ppm}$. Cara membuat larutan stok 1000 ppm, yaitu dengan melarutkan 
2,513 gram $\mathrm{CuSO}_{4}$ ke dalam $1 \mathrm{~L}$ aquadest. Larutan stok $\mathrm{Cu}$ berkonsentrasi $1000 \mathrm{ppm}$ diambil sebanyak $30 \mathrm{~mL}$ untuk membuat larutan $\mathrm{Cu}$ konsentrasi $1 \mathrm{ppm}$ pada $30 \mathrm{~L}$ media pemeliharaan.

Pupuk NPK (N;15\%; P:15\%; K:15\%) dimasukkan sebanyak 30 gram dalam setiap akuarium dan diaerasi agar homogen yang digunakan untuk meningkatkan pertumbuhan dan perkembangan Gracilaria gigas. Gracilaria gigas yang telah diaklimatisasi ditimbang dan dipilih yang terbaik sebanyak $400 \mathrm{~g}$ kemudian dibagi menjadi 2 bagian, yaitu 200 gram untuk mengukur pertumbuhan G. gigas dan 200 gram untuk mengukur konsentrasi logam berat tembaga $(\mathrm{Cu})$. Pengukuran parameter kualitas air (salinitas, $\mathrm{pH}$, dan suhu) dilakukan setiap hari dan pengukuran berat basah, berat mutlak, dan laju pertumbuhan spesifik (SGR) dilakukan setiap minggu. Preparasi sampel dilakukan dengan cara destruksi basah. Menurut Kristianingrum (2012), destruksi adalah proses pemecahan senyawa menjadi unsurunsurnya sehing-ga dapat dianalisis atau perubahan bentuk logam organik menjadi bentuk logam anorganik. Destruksi basah adalah perombakan sampel dengan asam-asam kuat baik tunggal maupun campuran, kemudian dioksidasi dengan menggunakan zat oksidator. Setelah proses destruksi selesai maka filtratnya diuji absorbansinya dengan menggunakan metode AAS dan data tersebut dilakukan analisa statistik.

\section{HASIL DAN PEMBAHASAN}

\section{Absorpsi Gracilaria gigas terhadap Logam $\mathrm{Cu}$}

Hasil pengukuran konsentrasi logam berat Tembaga $(\mathrm{Cu})$ yang diserap oleh Gracilaria gigas pada media pemeliharaan yang mempunyai salinitas berbeda disajikan pada Tabel 1 .

Hasil perhitungan (Tabel 1) nunjukkan bahwa absorpsi Gracilaria gigas terhadap logam berat $\mathrm{Cu}$ tertinggi terjadi pada perlakuan B $(10 \%)$ dengan rerata nilai 33,$10 ; 35,68 ; 36,51$; dan 39,61 ppm sedangkan hasil terendah terjadi pada perlakuan A (25\%) dengan rerata nilai 1,49; 2,$78 ; 1,48$; dan $2,58 \mathrm{ppm}$. Hasil uji statistik yang dilakukan menunjukkan bahwa data berdistribusi tidak normal dan tidak homogen, sehingga dilakukan uji non parametrik $(\mathrm{p}>0,05)$ yaitu 0,165 atau perlakuan salinitas yang berbeda tidak berpengaruh terhadap penyerapan logam berat tembaga $(\mathrm{Cu})$ pada Gracilaria gigas. Mekanisme absorpsi logam $\mathrm{Cu}$ Menurut Yulianto (2006), logam berat $\mathrm{Cu}$ masuk ke dalam dinding sel Gracilaria gigas dan diikat oleh protein dan polisakarida sehingga logam $\mathrm{Cu}$ dalam bentuk toksik $\left(\mathrm{Cu}^{2+}\right)$ berubah menjadi senyawa yang non toksik. Logam $\mathrm{Cu}$ dalam bentuk ion bebas $\left(\mathrm{Cu}^{2+}\right)$ tersebut menjadi toksik apabila masuk ke dalam bagian sel yang lebih dalam karena logam $\mathrm{Cu}$ akan berikatan dengan gugus senyawa penyusun enzim yang dapat menganggu aktivitas enzim sehingga

fisiologisnya terganggu. Terakumulasinya logam berat $\mathrm{Cu}$ pada dinding sel menyebabkan penyerapan zat hara terganggu karena dinding sel akan berubah dari semi permeable menjadi

permeable. Penyerapan logam berat $\mathrm{Cu}$ oleh dinding sel Gracilaria gigas tersebut akan masuk ke dalam sitoplasma yang kemudian di transportasi dan disimpan pada bagian dalam vakuola (medula). Perbedaan konsentrasi yang dihasilkan karena adanya perpindahan atau transfer massa $\mathrm{Cu}$ secara difusi dan osmosis.Menurut Yudiati et al. (2009), salinitas juga dapat mempengaruhi penyerapan logam berat $\mathrm{Cu}$, apabila terjadi penurunan salinitas karena adanya proses desalinasi maka logam berat akan mengalami peningkatan dan tingkat bioakumulasi logam berat semakin besar. Pada salinitas rendah akan terjadi peningkatan konsentrasi $\mathrm{Cu}$ karena membentuk molekul atau ion kompleks relatif kecil. Salinitas juga akan mempengaruhi proses osmotik dan ionik Gracilaria gigas yang akan menyebabkan stres ion, stres osmotik dan stres seku.

\section{Konsentrasi Logam $\mathrm{Cu}$ dalam Media Pemeliharaan}

Hasil pengukuran dan perhitungan konsentrasi logam $\mathrm{Cu}$ dalam media pemeliharaan rumput laut $G$. gigas dengan salinitas berbeda disajikan pada Tabel 2. Hasil perhitungan (Tabel 2) menunjukkan bahwa konsentrasi logam berat tembaga $(\mathrm{Cu})$ pada media pemeliharaan tertinggi terjadi pada perlakuan E (40\%) dengan rerata nilai 0,$11 ; 0,10 ; 0,12$; dan 0,17 ppm sedangkan hasil terendah terjadi pada perlakuan A $(25 \%)$ dengan rerata nilai 0,$02 ; 0,01 ; 0,02$; dan 0,02 ppm. Menurut Yuliana et al. (2015), hal tersebut karena terjadi stres ion. Stres ion terjadi apabila semakin tinggi salinitas maka akan terjadi keracunan $\mathrm{Na}^{+}$. Ion $\mathrm{Na}$ yang berlebihan pada permukaan thallus dapat menghambat serapan $\mathrm{Cu}^{2+}$ yang berfungsi untuk mempertahankan turgor sel dan aktivitas enzim dari lingkungan.

\section{Kapasitas dan Efektivitas Penyerapan Logam Cu oleh Gracilaria gigas}

Hasil perhitungan kapasitas penyerapan logam berat tembaga $(\mathrm{Cu})$ oleh Gracilaria gigas disajikan pada Tabel 3 , sedangkan efektivitas 
penyerapan logam $\mathrm{Cu}$ pada Tabel 4. Berdasarkan hasil perhitungan efektivitas penyerapan logam berat $\mathrm{Cu}$ oleh Gracilaria gigas tertinggi terdapat pada hari ke 7 perlakuan A (25\%), yaitu nilai rerata $82,77 \%$ dengan nilai rerata kapasitas penyerapannya $0,007 \mathrm{mg} / \mathrm{g}$ sedangkan nilai efektivitas penyerapan logam berat $\mathrm{Cu}$ oleh Gracilaria gigas terendah terdapat pada hari ke 28 perlakuan E (40\%), yaitu nilai rerata $-188,88 \%$ dengan nilai rerata kapasitas penyerapannya $0,017 \mathrm{mg} / \mathrm{g}$.

Menurut Yuliana et al. (2015), salinitas yang tidak sesuai mengakibatkan stres ion, stres osmotik dan stres sekunder. Stres ion terjadi apabila semakin tinggi salinitas maka akan terjadi keracunan $\mathrm{Na}^{+}$. Ion $\mathrm{Na}$ yang berlebihan pada permukaan thallus dapat menghambat serapan $\mathrm{Cu}^{2+}$ yang berfungsi untuk mempertahankan turgor sel dan aktivitas enzim dari lingkungan yang selanjutnya mengalami stres osmotik. Stres osmotik terjadi karena terlalu pekat media pemeliharaan yang menyebabkan tingginya tekanan osmotik sehingga menghambat penyerapan air dan unsur-unsur yang ada di lingkungan melalui proses osmosis. Menurut Arisandi et al. (2011), proses osmosis terjadi dari konsentrasi rendah ke konsentrasi tinggi atau kepekatan yang berbeda antara cairan dalam sel dengan media pemeliharaan mendorong badan golgi menggunakan energi yang lebih besar untuk menyeim-bangkannya dengan cara memindahkan air yang ada di dalam sel keluar menuju media pemeliharaan agar menjadi isotonis. Jumlah air yang masuk ke dalam sel akan berkurang yang menyebabkan persediaan air dalam sel menurun. Setelah itu akan terjadi stres sekunder yaitu penurunan kondisi fisik Gracilaria gigas, seperti thallus bewarna hijau tua, ujung thallus bewarna putih, tidak elastis, rapuh, dan berlendir. Kondisi fisik Gracilaria gigas yang menurun tersebut menyebabkan struktur sel dan makromolekul seperti lipid, enzim dan DNA menjadi rusak.

Tabel 1. Penyerapan Logam Berat Tembaga $(\mathrm{Cu})$ oleh Gracilaria gigas pada Media Pemeliharaan dengan Salinitas Berbeda

\begin{tabular}{cccccc}
\hline \multirow{2}{*}{$\begin{array}{c}\text { Waktu } \\
\text { (hari) }\end{array}$} & $\mathrm{T}(25 \%)$ & $\mathrm{B}(10 \%)$ & $\mathrm{C}(20 \%)$ & $\mathrm{D}(30 \%$ \%onsentrasi Logam Cu $(\mathrm{ppm})$ & $\mathrm{E}(40 \%)$ \\
\cline { 2 - 6 } & $0,56 \pm 0,00$ & $0,56 \pm 0,00$ & $0,56 \pm 0,00$ & $0,56 \pm 0,00$ & $0,56 \pm 0,00$ \\
7 & $1,49 \pm 0,55$ & $33,10 \pm 4,56$ & $30,59 \pm 2,53$ & $30,72 \pm 4,50$ & $28,98 \pm 4,20$ \\
14 & $2,78 \pm 0,78$ & $35,68 \pm 6,43$ & $32,14 \pm 3,84$ & $32,75 \pm 4,63$ & $27,83 \pm 1,02$ \\
21 & $1,48 \pm 0,37$ & $36,51 \pm 4,06$ & $35,59 \pm 1,37$ & $35,70 \pm 1,96$ & $32,41 \pm 1,13$ \\
28 & $2,58 \pm 0,83$ & $39,61 \pm 3,50$ & $34,25 \pm 1,67$ & $32,50 \pm 3,96$ & $29,80 \pm 0,87$ \\
\hline
\end{tabular}

Keterangan: $\mathrm{A}=$ Kontrol (salinitas $25 \%$ ); $\mathrm{B}=$ Konsentrasi logam berat tembaga $(\mathrm{Cu}) 1$ ppm dengan salinitas $10 \%$; $\mathrm{C}=$ Konsentrasi logam berat tembaga $(\mathrm{Cu}) 1 \mathrm{ppm}$ dengan salinitas $20 \%$; D = Konsentrasi logam berat tembaga $(\mathrm{Cu}) 1 \mathrm{ppm}$ dengan salinitas $30 \%$; $\mathrm{E}=$ Konsentrasi logam berat tembaga $(\mathrm{Cu}) 1 \mathrm{ppm}$ dengan salinitas $40 \%$

Tabel 2. Konsentrasi Logam Berat Tembaga (Cu) dalam Media Pemeliharaan Rumput Laut G. gigas dengan Salinitas yang Berbeda

\begin{tabular}{cccccc}
\hline \multirow{2}{*}{$\begin{array}{c}\text { Waktu } \\
\text { (hari) }\end{array}$} & $\mathrm{A}(25 \%)$ & $\mathrm{B}(10 \%)$ & $\mathrm{C}(20 \%)$ & $\mathrm{D}(30 \%)$ & $\mathrm{E}(40 \%)$ \\
\cline { 2 - 6 } & $0,02 \pm 0,001$ & $0,04 \pm 0,005$ & $0,05 \pm 0,005$ & $0,06 \pm 0,005$ & $0,11 \pm 0,00$ \\
7 & $0,01 \pm 0,01$ & $0,06 \pm 0,005$ & $0,07 \pm 0,01$ & $0,09 \pm 0,01$ & $0,10 \pm 0,01$ \\
14 & $0,02 \pm 0,005$ & $0,11 \pm 0,01$ & $0,09 \pm 0,01$ & $0,13 \pm 0,06$ & $0,12 \pm 0,02$ \\
21 & $0,02 \pm 0,00$ & $0,13 \pm 0,01$ & $0,10 \pm 0,00$ & $0,14 \pm 0,03$ & $0,17 \pm 0,02$ \\
\hline
\end{tabular}

Keterangan: $\mathrm{A}=$ Kontrol (salinitas $25 \%$ ); $\mathrm{B}=$ Konsentrasi logam berat tembaga $(\mathrm{Cu}) 1 \mathrm{ppm}$ dengan salinitas $10 \%$; $\mathrm{C}=$ Konsentrasi logam berat tembaga $(\mathrm{Cu}) 1 \mathrm{ppm}$ dengan salinitas $20 \%$; D = Konsentrasi logam berat tembaga $(\mathrm{Cu}) 1 \mathrm{ppm}$ dengan salinitas $30 \%$; E = Konsentrasi logam berat tembaga $(\mathrm{Cu}) 1 \mathrm{ppm}$ dengan salinitas $40 \%$ 
Tabel 3. Kapasitas Penyerapan Logam Berat Tembaga $(\mathrm{Cu})$ oleh Gracilaria gigas

\begin{tabular}{cccccc}
\hline \multirow{2}{*}{$\begin{array}{c}\text { Waktu } \\
\text { (hari) }\end{array}$} & $\mathrm{A}(25 \%)$ & $\mathrm{B}(10 \%)$ & $\mathrm{C}(20 \%)$ & $\mathrm{D}(30 \%)$ & $\mathrm{E}(40 \% \mathrm{o})$ \\
\cline { 2 - 6 } & $0,005 \pm 0,001$ & $0,001 \pm 0,001$ & $0,000 \pm 0,00$ & $-0,000 \pm 0,00$ & $-0,007 \pm 0,00$ \\
14 & $0,007 \pm 0,001$ & $-0,000 \pm 0,00$ & $-0,002 \pm 0,001$ & $-0,005 \pm 0,001$ & $-0,006 \pm 0,002$ \\
21 & $0,005 \pm 0,001$ & $-0,007 \pm 0,002$ & $-0,004 \pm 0,002$ & $-0,011 \pm 0,009$ & $-0,009 \pm 0,003$ \\
28 & $0,006 \pm 0,00$ & $-0,011 \pm 0,001$ & $-0,006 \pm 0,00$ & $-0,011 \pm 0,005$ & $-0,017 \pm 0,003$ \\
\hline
\end{tabular}

Keterangan: $\mathrm{A}=$ Kontrol (salinitas $25 \%$ ); $\mathrm{B}=$ Konsentrasi logam berat tembaga $(\mathrm{Cu}) 1$ ppm dengan salinitas $10 \%$; $\mathrm{C}=$ Konsentrasi logam berat tembaga $(\mathrm{Cu}) 1 \mathrm{ppm}$ dengan salinitas $20 \%$; D = Konsentrasi logam berat tembaga $(\mathrm{Cu}) 1 \mathrm{ppm}$ dengan salinitas $30 \%$; E = Konsentrasi logam berat tembaga $(\mathrm{Cu}) 1 \mathrm{ppm}$ dengan salinitas $40 \%$

Tabel 4. Efektivitas Penyerapan Logam Berat Tembaga $(\mathrm{Cu})$ oleh Gracilaria gigas selama

\begin{tabular}{llllll}
\hline \multirow{2}{*}{$\begin{array}{c}\text { Waktu } \\
\text { (hari) }\end{array}$} & \multicolumn{5}{c}{ Efektivitas Penyerapan (\%) } \\
\cline { 2 - 6 } & $\mathrm{A}(25 \%)$ & $\mathrm{B}(10 \%)$ & $\mathrm{C}(20 \%)$ & $\mathrm{D}(30 \%)$ & $\mathrm{E}(40 \%)$ \\
\hline 7 & $61,10 \pm 9,61$ & $22,21 \pm 9,62$ & $11,10 \pm 9,61$ & $-11,10 \pm 9,61$ & $-83,33 \pm 0,00$ \\
14 & $82,77 \pm 15,84$ & $-11,10 \pm 9,61$ & $-27,77 \pm 19,24$ & $-55,55 \pm 19,24$ & $-72,22 \pm 25,45$ \\
21 & $61,10 \pm 9,61$ & $-88,88 \pm 25,45$ & $-55,55 \pm 25,45$ & $-122,22 \pm 101,83$ & $-105,55 \pm 34,69$ \\
28 & $66,66 \pm 0,00$ & $-127,77 \pm 19,24$ & $-66,66 \pm 0,00$ & $-133,33 \pm 60,09$ & $-188,88 \pm 38,49$ \\
\hline
\end{tabular}

Keterangan: $\mathrm{A}=$ Kontrol (salinitas $25 \%$ ); $\mathrm{B}=$ Konsentrasi logam berat tembaga $(\mathrm{Cu}) 1$ ppm dengan salinitas $10 \%$; $\mathrm{C}=$ Konsentrasi logam berat tembaga $(\mathrm{Cu}) 1 \mathrm{ppm}$ dengan salinitas $20 \%$; D = Konsentrasi logam berat tembaga $(\mathrm{Cu}) 1 \mathrm{ppm}$ dengan salinitas $30 \%$; E = Konsentrasi logam berat tembaga $(\mathrm{Cu}) 1 \mathrm{ppm}$ dengan salinitas $40 \%$

\section{Berat Basah Gracilaria gigas}

Hasil pengukuran dan perhitungan berat basah Gracilaria gigas dalam media pemeliharaan yang mengandung logam berat $\mathrm{Cu}$ dengan salinitas berbeda disajikan pada Tabel 5. Hasil pengukuran (Tabel 5) menunjukkan bahwa terjadi penurunan berat basah pada setiap harinya, dan berat basah tertinggi terjadi pada hari ke 7 dengan rerata nilai A $(25 \%) 227,11 \mathrm{~g}$; B (10 \%o) 240,55 g; C (20 \%o) 236,44 g; D (30 \%o) 221,44 g; dan E (40\%) 203,77 g. Hasil terendah terjadi pada hari ke 28 dengan rerata nilai A $(25 \%) 158,00 \mathrm{~g}$; B $(10 \%) 157,11 \mathrm{~g}$; C (20\%) 163,55 g; D (30\%o) $148,66 \mathrm{~g}$; dan E (40 \%) 165,77 g. Hasil uji statistik menunjukkan bahwa data tidak berdistribusi normal dan homogen, untuk uji repeated measures ANOVA menunjukkan bahwa berbeda nyata dan ada interaksi secara signifikan. Pertumbuhan rumput laut dapat dilihat berdasarkan pertambahan berat basah tersebut. Perbedaan berat basah tersebut dikarenakan pada hari ke- 7 kebutuhan nutrisi Gracilaria gigas terpenuhi dari pupuk NPK dan lingkungan media pemeliharaan serta masuknya logam berat $\mathrm{Cu}$ dijadikan sebagai sumber energi utama untuk sintesis protein, lemak, membran sel serta serapan hara secara aktif. Seiring dengan bertambahnya hari, maka akumulasi logam berat akan meningkat karena terjadi stes ion, osmotik, dan stres sekunder, sehingga pada hari ke- 28 pertumbuhan menurun. Menurut Saputra et al. (2013), pertumbuhan harian yang baik yaitu diatas $2 \%$. Perbedaan hasil tersebut dikarenakan jenis dan kualitas rumput laut serta kondisi lingkungan yang tidak mendukung. Pergerakan air atau aerasi juga mempengaruhi pertumbuhan rumput laut karena fungsinya dalam transportasi unsur hara, serta pengadukan air pada kolom air. Faktor kecerahan juga mempengaruhii dalam proses fotosintesis bagi pertumbuhan rumput laut. Jika kebutuhan sumber cahaya untuk berfotosintesis terpenuhi maka hasilnya dijadikan sebagai cadangan makanan dan oksigen digunakan dalam proses pertumbuhannya. Menurut Hasan et al. (2015), salinitas merupakan salah satu parameter kualitas air yang mempengaruhi pertumbuhan, pembentukan thallus dan perkembangan morfogenetik rumput laut. Hal tersebut dikarenakan salinitas berperan dalam proses osmoregulasi yang terjadi dii dalam sel. Pada salinitas 10 dan $20 \%$ tidak mengalami perbedaan ukuran yang signifikan, tetapi pada salinitas 30 
dan $40 \%$ mengalami perubahan yang signifikan karena adanya proses osmosis. Hal tersebut meyebabkan terhambatnya penyerapan air dan unsur lainnya. Menurut Arisandi et al. (2011), salinitas mempengaruhi pertumbuhan rumput laut yang sangat kompleks. Salinitas menyebabkan stress ion, stres osmotik dan stres sekunder. Kisaran salinitas tidak sesuai dengan kisaran hidup rumput laut maka pertumbuhan dan perkembangan selnya berbanding terbalik (negatif) dengan kenaikan salinitas.

\section{Pertumbuhan Mutlak Gracilaria gigas}

Berdasarkan hasil perhitungan (Tabel 6) menunjukkan bahwa berat mutlak terdapat tanda negatif, yang artinya tidak ada pertumbuhan pada Gracilaria gigas selama 28 hari pemeliharaan. Hasil uji statistik yang telah dilakukan menunjukkan bahwa data berdistribusi normal atau ( $>>0,05)$. Uji homogenitas yang di dapat $(p>0,05)$ yang artinya data tersebut homogen. Uji
ANOVA menghasilkan pertumbuhan mutlak Gracilaria gigas antar perlakuan sama. Pertumbuhann mutlak tersebut dihasilkan dari perhitungan antara selisih berat basah pada akhir penelitian dengan berat basah awal penelitian. Hasil ini sesuai dengan penelitian sebelumnya yang dilaporkan oleh Supriyantini et al. (2018), bahwa tidak terjadi pertumbuhan yang signifikan terhadap rumput laut Gracilaria sp.yang dipelihara dalam media yang mengandung konsentrasi logam $\mathrm{Cu}$ yang berbeda selama 28 hari.Tidak terjadinya pertumbuhan pada rumput laut $G$. gigas diduga karena rumput laut banyak menyerap logam $\mathrm{Cu}$ yang ada di dalam media pemeliharaan, sehingga mengganggu proses metabolisme yang selanjutnya akan menghambat pertumbuhan rumput laut tersebut. Logam $\mathrm{Cu}$ merupakan mikronutrien esensial tetapi jika jumlahnya melebihi batas tolerir kebutuhan organisme maka akan bersifat toksik.

Tabel 5. Berat Basah Gracilaria gigas dalam Media Pemeliharaan yang Mengandung Logam Berat Tembaga $(\mathrm{Cu})$ dengan Salinitas yang Berbeda

\begin{tabular}{clllll}
\hline Waktu (hari) & \multicolumn{5}{c}{ Berat Basah G. gigas $(\mathrm{g})$} \\
\cline { 2 - 6 } & A $(25 \%)$ & $\mathrm{B}(10 \%)$ & $\mathrm{C}(20 \%)$ & $\mathrm{D}(30 \%)$ & $\mathrm{E}(40 \% \mathrm{o})$ \\
\hline 0 & $200,00 \pm 0,00$ & $200,00 \pm 0,00$ & $200,00 \pm 0,00$ & $200,00 \pm 0,00$ & $200,00 \pm 0,00$ \\
7 & $227,11 \pm 6,53$ & $240,55 \pm 7,98$ & $236,44 \pm 2,54$ & $221,44 \pm 13,53$ & $203,77 \pm 3,90$ \\
14 & $197,66 \pm 4,50$ & $205,88 \pm 17,97$ & $216,77 \pm 3,26$ & $197,32 \pm 17,89$ & $192,32 \pm 7,50$ \\
21 & $170,33 \pm 5,36$ & $162,77 \pm 18,09$ & $175,10 \pm 10,54$ & $161,10 \pm 15,67$ & $148,66 \pm 11,01$ \\
28 & $158,00 \pm 19,97$ & $157,11 \pm 15,77$ & $163,55 \pm 11,04$ & $178,11 \pm 15,79$ & $165,77 \pm 17,91$ \\
\hline
\end{tabular}

Keterangan: $\mathrm{A}=$ Kontrol (salinitas $25 \%$ ); $\mathrm{B}=$ Konsentrasi logam berat tembaga $(\mathrm{Cu}) 1$ ppm dengan salinitas $10 \%$; $\mathrm{C}=$ Konsentrasi logam berat tembaga $(\mathrm{Cu}) 1 \mathrm{ppm}$ dengan salinitas $20 \%$; D = Konsentrasi logam berat tembaga $(\mathrm{Cu}) 1 \mathrm{ppm}$ dengan salinitas $30 \%$; E = Konsentrasi logam berat tembaga $(\mathrm{Cu}) 1 \mathrm{ppm}$ dengan salinitas $40 \%$

Tabel 6. Pertumbuhan Mutlak (g) Gracilaria gigas dalam Media yang Mengandung Logam Berat Tembaga $(\mathrm{Cu})$ dengan Salinitas yang Berbeda

\begin{tabular}{cccc}
\hline Perlakuan & Wo & Wt & G \\
\hline A (25\%) & 200,00 & $158,00 \pm 19,97$ & $-42,00 \pm 19,97$ \\
B (10\%) & 200,00 & $157,11 \pm 15,77$ & $-42,89 \pm 15,77$ \\
C (20\%) & 200,00 & $163,55 \pm 11,04$ & $-36,44 \pm 11,04$ \\
D (30\%) & 200,00 & $148,66 \pm 11,01$ & $-51,33 \pm 11,01$ \\
E (40\%) & 200,00 & $165,77 \pm 17,91$ & $-34,22 \pm 13,76$ \\
\hline
\end{tabular}

Keterangan: $\mathrm{A}=$ Kontrol (salinitas $25 \%$ ); $\mathrm{B}=$ Konsentrasi logam berat tembaga $(\mathrm{Cu}) 1$ ppm dengan salinitas $10 \%$; $\mathrm{C}=$ Konsentrasi logam berat tembaga $(\mathrm{Cu}) 1 \mathrm{ppm}$ dengan salinitas $20 \%$; D = Konsentrasi logam berat tembaga $(\mathrm{Cu}) 1 \mathrm{ppm}$ dengan salinitas $30 \%$; $\mathrm{E}=$ Konsentrasi logam berat tembaga $(\mathrm{Cu}) 1 \mathrm{ppm}$ dengan salinitas $40 \%$ 
Hasil perhitungan (Tabel 7) menunjukkan bahwa terdapat tanda negatif, yang artinya tidak ada laju pertumbuhan spesifik (SGR) pada Gracilaria gigas selama 28 hari pemeliharaan. Hasil uji statistik yang telah dilakukan menunjukkan bahwa $(p>0,05)$ yang artinya data berdistribusi normal. Uji homogenitas menghasilkan $(\mathrm{p}>0,05)$ yang artinya data tersebut homogen. Uji ANOVA menghasilkan laju pertumbuhan Gracilaria gigas antar perlakuan sama. Nilai SGR yang dihasilkan tersebut merupakan laju pertumbuhan secara spesifik baik secara berat, ukuran, dan volume seiring dengan perubahan waktu pada setiap

Tabel 7. Laju Pertumbuhan Spesifik (SGR) Gracilaria gigas dalam Media Logam Berat Tembaga dengan Salinitas yang Berbeda

\begin{tabular}{cccc}
\hline Perlakuan & Ln Wo & Ln Wt & SGR (\% per hari) \\
\hline A (25\%) & 5,30 & $5,05 \pm 0,12$ & $-0,88 \pm 0,43$ \\
B (10\%) & 5,30 & $5,04 \pm 0,09$ & $-0,90 \pm 0,34$ \\
C (20\%) & 5,30 & $5,09 \pm 0,06$ & $-0,74 \pm 0,23$ \\
D (30\%) & 5,30 & $4,99 \pm 0,07$ & $-0,98 \pm 0,14$ \\
E (40\%) & 5,30 & $5,10 \pm 0,08$ & $-0,70 \pm 0,28$ \\
\hline
\end{tabular}

Keterangan: $\mathrm{A}=$ Kontrol (salinitas $25 \%$ ); $\mathrm{B}=$ Konsentrasi logam berat tembaga $(\mathrm{Cu}) 1 \mathrm{ppm}$ dengan salinitas $10 \%$; $\mathrm{C}=$ Konsentrasi logam berat tembaga $(\mathrm{Cu}) 1 \mathrm{ppm}$ dengan salinitas $20 \%$; D = Konsentrasi logam berat tembaga $(\mathrm{Cu}) 1 \mathrm{ppm}$ dengan salinitas $30 \%$; E = Konsentrasi logam berat tembaga $(\mathrm{Cu}) 1 \mathrm{ppm}$ dengan salinitas $40 \%$

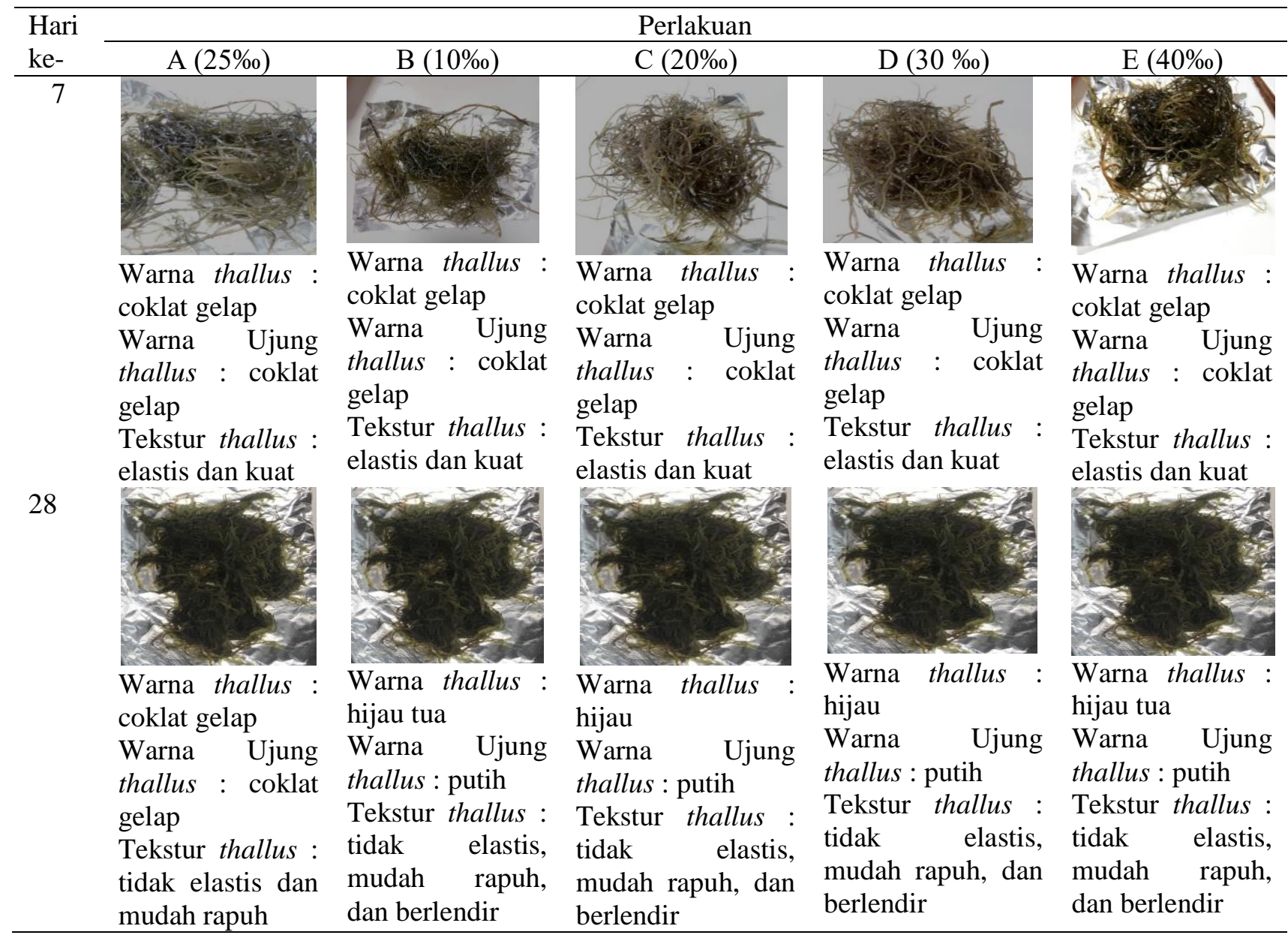

Gambar 1. Pengamatan visual Gracilaria gigas selama pemeliharaan 28 hari 
harinya. Tidak terjadinya pertumbuhan yang spesifik selama 28 hari pemeliharaan diduga disebabkan oleh perlakuan salinitas yang berbeda yang ada dalam media pemeliharaan rumput laut yang mengandung logam berat $\mathrm{Cu}$.

\section{Laju Pertumbuhan Spesifik (SGR) Gracilaria gigas}

Hasil pengukuran dan perhitungan laju pertumbuhan spesifik (SGR)Gracilaria gigas selama pemeliharaan 28 hari dalam media yang mengandung logam berat $\mathrm{Cu}$ dengan salinitas yang berbeda disajikan pada Tabel 7 .

Pengamatan visual pada Gracilaria gigas meliputi pengamatan warna dan tekstur thallus selama 28 hari pemeliharaan. Hasil pengamatan (Gambar 1) menunjukkan warna thallus Gracilaria gigas pada tiap perlakuan A (25\%), B $(10 \%)$, C $(20 \%)$, D (30\%), dan E (40\%) pada awal penanaman memiliki warna coklat gelap, tidak pucat, dan sehat. Hari ke- 7 semua perlakuan memiliki warna yang sama seperti awal pemeliharaan, tetapi pada hari ke- 14 dan 21 terjadi perubahan warna dari coklat menjadi warna hijau. Hari ke 28 pada perlakuan A ( $25 \%$ ) dan E (40 \%o) mengalami perubahan warna menjadi hijau tua sedangkan pada perlakuan B (10 $\%)$, C (20 \%o), dan D (30 \%o) tidak terjadi perubahan warna atau tetap warna hijau. Hari ke 28 semua perlakuan mengalami perubahan warna menjadi putih. Hasil pengamatan tekstur thallus Gracilaria gigas menunjukkan awal pemeliharaan sampaii hari ke-7 memiliki tekstur yang elastis dan kuat. Pada hari ke- 14 memiliki tekstur yang tidak elastis dan mudah rapuh kecuali pada perlakuan C (20\%) dan D (30 \%) yang masih elastis dan kuat. Hari ke- 28 teskturnya sama pada setiap perlakuan berubah menjadi tidak elastis, mudah rapuh, dan berlendir.

\section{KESIMPULAN}

Berdasarkan hasil penelitian, dapat disimpulkan bahwa perlakuan salinitas yang berbeda tidak berpengaruh terhadap absorpsi $\mathrm{Cu}$ pada Gracilaria gigas ( $>0,05)$. Kemampuan Gracilaria gigas dalam menurunkan kadar logam berat $\mathrm{Cu}$ pada media pemeliharaam tertinggi terdapat pada salinitas $10 \%$ dengan rerata nilai 33,$10 ; 35,68 ; 36,51$, dan 39,61 ppm. Hasil pertumbuhan tertinggi terjadi pada hari ke-7 dengan rerata nilai, yaitu salinitas $25 \% 227,11 \mathrm{~g}$; salinitas $10 \%$ 240,55 g; salinitas $20 \%$ o 236,44 g; salinitas $30 \%$ 221,44 g; dan salinitas $40 \%$ 203,77 g. Semakin tinggi salinitas, maka pertumbuhan Gracilaria gigas akan semakin rendah.

\section{DAFTAR PUSTAKA}

Arisandi, A., Marsoedi, M., Nursyam, H. \& Sartimbul, A., 2011. Pengaruh salinitas yang berbeda terhadap morfologi, ukuran dan jumlah sel, pertumbuhan serta rendemen karaginan Kappaphycus alvarezii. Ilmu Kelautan: Indonesian Journal of Marine Sciences, 16(3):143-150.

Bath, D.S., Siregar, J.M. \& Lubis, M.T. 2012. Penggunaan Tanah Bentonit sebagai Adsorben Logam Cu. Jurnal Teknik Kimia USU., 1(1):1-4.

Hasan, M.R., Rejeki, S. \& Wisnu, R. 2015. Pengaruh Bobot Awal yang Berbeda terhadap Pertumbuhan Gracilaria sp. yang Dibudidayakan dengan Metode Longline di Perairan Tambak Terabrasi Desa Kaliwlingi Kabupaten Brebes. Journal Aquaculture Management and Technology., 4(2):92-99.

Juhaeti, T., Syarif, F. \& Hidayati, N. 2005. Inventarisasi Tumbuhan Potensial untuk Fitoremediasi Lahan dan Air Terdegradasi Penambangan Emas. Jurnal Biodiversitas., 6(1): 31-33.

Kristianingrum, S. 2012. Kajian berbagai Proses Destruksi Sampel dan Efeknya. Prosiding Seminar Nasional Penelitian, Pendidikan dan Penerapan MIPA, Fakultas MIPA, Universitas Negeri Yogyakarta. 2 Juni 2012.

Ma'ruf W.F., Ibrahim, R., Dewi, E.N., Susanto, E. \& Amalia, U. 2013. Profil Rumput Laut Caulerpa Racemosa dan Gracilaria verrucosa sebagai Edible Food. Jurnal Saintek Perikanan, 9(1):68-74.

Phillips, G.O \& Peter, A.W. 2000. Handbook of Hydrocolloids, Woodheat Publishing Limited, England.

Qumain S., Dharmawan, A. \& Prabaningtyas, S.. 2015. Analisis Perbandingan Kandungan Logam Berat Timbal $(\mathrm{Pb})$ pada Rumput Laut Gracillaria sp. dan Agar Desa Kupang, Kecamatan Jabon, Sidoarjo. Maspari Jurnal., 4(2):42-50.

Saputra, R., Patadjai, R.S. \& Balubi, A.M. 2013. Analisa Pertumbuhan dan Kadar Karaginan Rumput Laut Kappaphycus alvarezii pada Lokasi Berbeda di Perairan sekitar Penambangan Kecamatan Lasolo Kabupaten Konawe Utara. Jurnal Mina Laut Indonesia, 3(12):55-67. 
Sjafrie, N.D.M. 1990. Beberapa Catatan Mengenai Rumput Laut Gracilaria. Jurnal Oseana, 15(4):147-155.

Supriyantini, E., Santosa, G.W. \& Alamanda, L.N.. 2018. Pertumbuhan Rumpu Laut Gracilaria sp. pada Media yang Mengandung Tembaga $(\mathrm{Cu})$ dengan Konsentrasi yang berbea. Buletin Oseanografi, 7(1):15-21.

Yudiati, E., Sedjati, S., Enggar, I. \& Hasibuan, I. 2009. Dampak Pemaparan Logam Berat Kadmium pada Salinitas yang Berbeda terhadap Mortalitas dan Kerusakan Jaringan Insan Juvenile Udang Vaname (Litopeneus vannamei). Ilmu Kelautan: Indonesian Journal of Marine Sciences, 14(4): 29-35.
Yuliana, A., Rejeki, S. \& Widowati, L.L. 2015. Pengaruh Salinitas yang Berbeda terhadap Pertumbuhan Rumput Laut Latoh (Caulerpa Lentillifera) di Laboratorium Pengembangan Wilayah Pantai (LPWP) Jepara. Journal of Aquaculture Management and Technology, 4(4):61-66.

Yulianto, B. 2006. Daya Serap Rumput Laut (Gracillaria sp.) terhadap Logam Berat Tembaga $(\mathrm{Cu})$ sebagai Biofilter. Ilmu Kelautan: Indonesian Journal of Marine Sciences, 11(2):72-78. 